\title{
sciendo
}

Research Article

(C) 2019 Alieva et.al.

This is an open access article licensed under the Creative Commons Attribution-NonCommercial-NoDerivs License (http://creativecommons.org/licenses/by-nc-nd/3.0/).

\section{Scientific and Pedagogical Bases of Civic and Patriotic Upbringing of Young Students}

\author{
Sariat A. Alieva \\ Siadat Z. Zakaryaeva \\ Omarkhan N. Omarov \\ Raisa V. Radjabova \\ Elmira A. Kimpaeva \\ Patimat D. Gadjieva \\ Dagestan State Pedagogical University, \\ Makhachkala, Republic of Dagestan, Russia
}

Doi: 10.2478/jesr-2019-0033

\begin{abstract}
The experience accumulated by pedagogical theory and practice of patriotic and civic upbringing of children and youth is currently undergoing a profound positive conceptualization and evaluation. The relevance of the problem under study is associated with the circumstance that under certain historical conditions there takes place purification, updating and manifestation of Russian values in the interests of the entire Homeland, both "smaller" and "greater" Motherland. The objective of this research is to find out scientific and pedagogical bases for the essence and content of civic and patriotic upbringing of young students at the contemporary stage. The leading principle of studying this problem is the principle of particular historical approach which implies matching the content, forms and methods of patriotic and civic upbringing in a certain historical situation. In this paper, the authors discuss the problems of patriotism and civic spirit in various historical, social and political, and economic conditions depending on their views influenced by the knowledge acquired and the personal civic stance developed under the effect of various factors, as well as attitude to their Homeland.
\end{abstract}

Keywords: patriotic upbringing, civic upbringing, young students, civic rights and liberties, civic values

\section{Introduction}

Recently, the trends of turning to the traditions of the past have taken shape. Priority is given to the generally recognized Russian experience and the new knowledge of patriotic upbringing in the variety of ideas, approaches and studies conducted. The analysis of works researching the problem of patriotism shows the versatility and ambivalence of treatment of the notion "patriotism", which explains the range of variants of using it. Largely, this is due to the complicated nature of this phenomenon, multiple aspects of its content, original structure and diversity of forms of its manifestation.

"Patriotism, - E. S. Stroev (2001) writes, - is a natural manifestation of profound sincere feelings of a human, a vital need of the human. It embodies in itself the love for one's family and for the Homeland, adherence to one's faith, respect and reverence to the deeds of the ancestors, a 
wish to serve selflessly to one's native country, the community in which one lives" (p. 77). K. D. Ushinsky (1968) believed love for one's Homeland was a characteristic feature of the Russian people and Motherland had to be loved not only when it was in danger but also by honestly serving it in the peaceful daily life. Another fellow citizen, philosopher V. V. Rozanov (1980) said "it is no great accomplishment to love a fortunate and grand motherland. It is when she is weak, small, humbled, even stupid, even depraved - that we should love her. Precisely, exactly when our "mother" is drunk, when she tells lies, when she gets all tangled up in sinfulness - that is when we are obliged not to leave her" (p. 116).

In the contemporary conditions, as the state policy in the domain of upbringing offers no real ways out of the spiritual crisis permeating the entire society, it is the experience of the ancestors and the sources of one's national values that one should turn to. In Dagestan, especially in its mountainous and submountain areas where the majority of population lives, they have paid close attention to bringing up the love for one's native land, Motherland since early childhood. This is noted by academician N. D. Nikandrov (2003), too: "I would like to highlight it once more, referring not so much to studies rather than to experience of all times and peoples that one's understanding of one's ethnic and national belonging, the value of one's culture, the love for one's Motherland - all these things commence with the nearest circle and only later do they expand up to the general human but they are never brought down to it" (p. 14). According to I. A. llyin (1995), it is patriotism that demonstrates that there is a summit from which one can get a view of the universal brotherhood, brotherhood of all people in front of God's face. The great thinker of religion and philosophy, N. A. Berdyaev (1920) pointed out that "only one who feels and knows one's own national soul can feel and know another one's national soul" (p. 81). In the opinion of V. S. Soloviev (2019), moral liability of a true patriot is to serve the people in a man and the mankind in the people.

These ideas are aligned with the requirements set by the older generations of the Dagestani for upbringing of children and youth, when forming the feeling of love for their Motherland in them. At the same time the authors would like to mention that the contemporary generations of mountaineers of Dagestan are ready to move toward the universal human culture yet bearing in mind their original values that have been tested out and proven by thousand-year practice and have become traditional.

\section{Literature Review}

At present, with various social and economic changes (Tarman \& Chigisheva, 2017) and the country's leading national idea still being elaborated, in the works of many Russian thinkers, various viewpoints on the phenomenon of patriotism as the core component of the idea designed to serve association and consolidation of the Russian nation, Russian public and state are described.

The works of pedagogues (Bazilevich, 1982; Boldyrev, 1949; Gasanov, 1998) cover a broad range of questions of patriotic upbringing of the rising generation. Thesis paper studies (Bazilevich, 1982; Boldyrev, 1949; Terentiy, 1978) have the general theoretical character and show the association of patriotic upbringing with other constituents of upbringing, with forms and methods of patriotic upbringing explored, too.

The works by A. D. Soldatenko (1994), V. I. Shakhnenko (1984) et al. deal with diagnosing patriotic upbringing in senior school students. Various means for forming patriotism in senior school students are analyzed in the studies by A. D. Vanshtein (2011), Z. T. Gasanov (1999), L. Sh. Ighenberdieva (2006) et al.

Such authors as N. I. Boldyrev (1949), Sh. I. Ganelin (2011) define the essence of Soviet patriotism as a moral quality of an individual and consider the problems of forming the patriotic knowledge and feelings in students within the system of classes.

The analysis of pedagogical literature and thesis papers has enabled the authors to make the conclusion that there are various treatments of patriotism: some consider patriotism to be a moral principle; other researchers view it as a new type of expressing feelings of the Soviet national pride; yet other ones - as the feeling of love for one's Motherland.

It is only a few scientists who point out that patriotism has to be brought up as a quality of personality (Akhayan, 2016; Belyaev, 1997; Mishchenko, 1982; Terentiy, 1978). 
Thus, patriotism to be brought up in children and youth can be considered as an attitude, a feeling, a quality the content of which is love for one's Motherland, devotion to it, pride in its heroic past and present, intention to defend the country's interests, and working for the benefit of one's Motherland.

The theory of dependence between moral behavior and consciousness is of great importance for the process of bringing up patriotism (Vygotsky, 1991; Leontiev, 1975; Rubinshtein, 1997). There is no doubt consciousness produces a decisive influence on people's moral behavior.

\section{Methodological Framework}

The objective of this research is to find out scientific and pedagogical bases for civic and patriotic upbringing of young students at the contemporary stage.

There are the following tasks:

- to detail the essence and content of the notion "patriotism";

- to identify creative works of national writers and poets who have dedicated their best works to shaping and understanding the essence of the "Russian patriotism";

- to detail the essence and content of the notion "civic spirit";

- to identify civic values;

- to find out efficient folk traditions forming the civic spirit and patriotism in children and youth;

- to identify efficient forms, methods and means of civic and patriotic upbringing of children and youth at general educational institutions.

Methods of the research are as follows:

- theoretical learning methods: comparison, generalization, modeling;

- methods of studying the learners within natural conditions of the educational and upbringing process: pedagogical observation, survey, interview;

- methods of experiment and pedagogical monitoring.

\section{Results and Discussion}

The problems of bringing up patriotism and civic spirit have deep roots in history; they emerged back in the primitive society, as the old ones brought up the young generations in the spirit of devotion to their kindred, tribe, traditions and customs established in the community. In the subsequent epochs, these problems were solved depending on the requirements of a particular social and economic formation.

The notion "patriotism" (stemming from the Greek word "patriotec" meaning "countryman", "fellow citizen") expresses the feeling of love for one's Motherland, devotion and readiness to serve it and defend it against foreign enemies. Loving and valuing one's native land, the country where one was born and one lives has been a tradition since the origin of man. Detailing the essence of the notion "patriotism" as applied to Russia, professor Z. T. Gasanov (1999) writes: "Russian patriotism is the attitude of citizens to their Motherland" (p. 107), the Russian Federation; it is expressed in readiness to serve it and defend it. This is the attitude to the country's vast expanses, natural wealth, heroic historical past and the controversial realia of today, the peoples populating it, their national dignity, cultures, traditions, and fellow citizens. Friendship of the peoples of Russia and the Russian patriotism are mutually related and complement each other. This is explained by the fact that in a multi-national state the national (something inherent in individual peoples) and the civic and patriotic (inherent in the entire federation) are combined as the general and the particular. Under these conditions, patriotism does not disconnect or isolate the country's nations but brings them closer together and unites into the single federation. Russian patriotism does not oppose the country's peoples to each other but it consolidates them within the single Federation, reinforces their relationships with peoples of the CIS and other foreign countries. In Russian patriotism, the general Russian feeling of a citizen is combined with the feeling of the citizen's smaller Motherland, native republic, region or national district.

The extent to which the feeling of patriotism is important for people was expressed by the 
great A. S. Pushkin (2005) in his poem:

"Two feelings are wondrously close to us,

In them our hearts find nourishment:

The love of our native hearth,

The love of our ancestral graves,

Life-giving holy place!" (p. 132).

This question was also addressed by M. A. Goncharov (2003) who expressed his stance on it as follows: "Patriotism is the feeling of love for one's Motherland embodied in serving its root interests, a kind of force to cement the ethnos or a group of ethnoses. Bond to one's Homeland is a particular product of spirituality. This can be seen from the history of our country, from the meaning of the national civilization that has formed over centuries. Patriotism relies on the act of spiritual self-identification" (Goncharov, 2003, p. 145). Later the author explains that once the Russian state formed, patriotism gained a particular importance for life; under Peter I patriotism acquired the nature of the state ideology and came to be considered higher than all values and virtues, with the words "God, tsar and Homeland" becoming the main motto of the Russians. It is military and patriotic upbringing significantly developed in works of A. V. Suvorov (1942), V. A. Kornilov (2010), and M. I. Dragomirov (1956) that became the core of the state patriotism.

Motherland, Homeland implies both the land with its historically formed boundaries, its natural wealth and landscapes, the language and culture of the people, their faith and mentality, and the very people - keeper, master and creator of everything, their present, historical past and the future. The feeling of Motherland is closely connected to that of national belonging, the association having formed in history. It should be specifically pointed out here that realizing one's national belonging and feeling of the national mentality implies a careful, respectful attitude to other nations and their ethnic and cultural particularities, too. A person having the national dignity never injures the national dignity of others. An attempt to humiliate other nations emerges only then and there as one feels one's national inferiority. However, on the other hand, the historically formed national selfidentification is a fairly important mechanism for preserving and developing the wealth of the Russian national culture. Homeland, Motherland is not merely a place where one was born; this is the root where one's kindred and one's people, fathers, grandfathers and fellow citizens stem from. A child may be born in another country where the child's parents work temporarily. However, this country does not become the child's Motherland, as the root of the child's kindred does not lie there. One can change one's citizenship but changing one's Motherland, Homeland is beyond one's forces - just like grubbing up the centuries-old roots of one's kindred from the native land. Hence, whatever the political or other orientation of a person may be, the notion of patriotism in its general features has to be brought across the person's consciousness, it has to be comprehended profoundly and realized in the respect of inseparability of oneself and one's homeland regardless of the extend of distance away from it. So, patriotism is the attitude to one's Motherland based on conscious love, respect and reverence, and the true love is inseparable from duty and it generates a certain notion about one's duty stemming from love. One's patriotic self-awareness is associated with identifying oneself as a loving, honest and devoted child of one's Homeland.

When defining the notion "patriotism", professor of Moscow State Social University R. Z. Khairullin (2003) places a high value on creative works of national writers and poets who have dedicated their best works to shaping and understanding the essence of the "Russian patriotism". Life and creativity of $\mathrm{M}$. Jalil is a perfect example of serving one's Motherland. The prisoner poet showed unparalleled courage. He did not lose his heart while in prison; he arranged escapes from the concentration camp having gathered his fellow countrymen into the underground organization Volga-Ural. Before death, he was a moral support for his friends. The poet realized that patriotic poems written by him had to determine the relevant style of his behavior, too, that his word (poetry) had to match his deed. The poet lived a decent life and believed his death would not be in vain:

"It was songs that taught me freedom to prize,

Now they bid me to die as a Fighter.

My life was a love-song that soared to the skies,

Let my death be the battle-song of a fighter" (Khairullin, 2003, p. 297)

There is good material for bringing up students in the spirit of patriotism in R. Gamzatov's 
book "My Dagestan" (1972). The topic of Motherland - smaller and greater - is the leading one in the book. The poet is proud of his native Dagestan, its glorious history and culture. The poet sees his mission in being the connecting link between his smaller Motherland and the big world. "To whatever lands destiny might toss me, - Rasul Gamzatov writes, - everywhere I feel a representative of that land, those mountains, and that aul where I learned to saddle up a horse. Everywhere I consider myself to be a special representative of Dagestan. However, I come back to my Dagestan as a special correspondent of the universal human culture, as a representative of the entire our country and even the entire world" (p. 301).

According to the authors, the above cited definitions of the essence of the notion "patriotism" cover all the main components of the content of the word "patriotism" denoting first of all love for one's Motherland, for one's native land where one and one's ancestors, one's people were born, as well as the total of cultural, spiritual and moral values, where certain traditions and customs, mentality, religious values were formed and relying on them certain relationships between people were established (ones of kinship, friendship, neighborhood, nation, labor etc.), where since childhood one has learned to love one's land with the natural climatic, physical geographic, social and economic conditions inherent in it that have produced a favorable impact on one's rise and further development as a representative of this nationality.

"The notions of "patriotism" and "civic spirit" (originating from the word "citizen") are close and sometimes even inseparable from each other. A citizen is a person belonging to the resident population of the particular state, using its protection and having the total of political and other rights and liabilities vested in the person, i.e. citizenship means legal belonging of the person to the state. A person being a citizen is subject to the state's laws, established rights and liabilities. Civic rights and liberties are the basis of constitutional legal status of the citizen of the state; they determine the possibilities of the person's participating in political, social and cultural life of the society. The main rights and liberties of citizens are under control of the world community and international organizations, too. The rise of the civic society represents a process in which both citizens, civic relationships between members of the public, and the society itself as the collective principle of the civic spirit participate" (Rogova, 2003, p. 307).

Among the civic values, there are trust in the public ideals, trust in the state, in Homeland, love for Homeland, for Motherland; affection to one's home, the very home and family as the value of family hearth, as well as civic forms of freedom - Equality, Justice, and Democracy. At every point of their lives, everyone is simultaneously not only a citizen, but also a family person, a student, a worker, a teacher and creator of the beautiful, an advocate of healthy way of life. Being a citizen, one has to be both patriot and humanist, too. Civic values act as objectives of civic upbringing: bringing up the trust in the public ideals, trust in the state; bringing up the love for Homeland; bringing up citizens and patriots; improving the culture of international and interethnic relationships; bringing up law abidance; shaping a respectful attitude to rights of children in line with the UN Convention on the Rights of the Child (1987); bringing up honor and dignity. The systemforming quality is civic spirit including the complex of subjective qualities of an individual. According to academician G. N. Filonov (2003), "it is the conscious law abidance, patriotic devotion in serving one's Motherland and defending the interests of one's Homeland; the truly free and honest adherence to orienting to generally accepted norms and moral values including the spheres of labor, family and daily life, international and interpersonal relations. Civic spirit is a condition of a person and citizen that lets and makes the person think, act and feel not only from the standpoint of one's personal welfare but also taking into account the welfare of one's fellow citizens and, probably, the entire mankind. With regard to this, a person sharing such views has the right to count on the relevant attitude of the public to the person, i.e. on respecting the person's human dignity and rights" (p. 50). Such understanding of the civic spirit has existed in the European culture so far, in particular, in the experience of France in civic and law-related upbringing of schoolchildren, France being one of the first countries in Europe to raise the problem of civic spirit.

The problem of "moral and civic virtues" was first put up by A. N. Radishchev (2000). It is the one who loves one's people, fights the injustice selflessly, is hardworking, modest, and instinct with high human dignity who is the true son of one's Homeland.

In her paper "From a citizen of a country to a citizen of the world", T. V. Plakhova (2003) 
(Samara) writes: "The beginning of the new century was marked by considerable upheavals for the entire humanity. What remains clearly unshakable are the eternal human ideals and values, civic spirit being an integral quality of people, trust in the fact that we and our society can be saved by faithfully serving to Motherland and the people, our responsibility for everything happening in the country and in the world, our decency, our tolerance, the wish to maintain dialogue with others at the level of a high morality and high culture. And, therefore, there arises a question about bringing up such a person as to undertake the civic responsibility not only for the person's own destiny but also for that of the person's people, for the destiny of the person's long-suffering Motherland called Russia" (p. 193). Alongside with that, the author believes quite fairly that such social institutions are school, family, mass media, the state and power-related structures, as well as teachers having so much focused in their hands - if the state realizes it. As for the more efficient system of upbringing, it has to provide for the formation of not only a citizen of one's Homeland, but also a citizen of the world. The author suggests the following conceptual bases for solving these problems:

The objective of upbringing: Human + Personality + Citizen.

Ideals: the Good, Reality, Truth, Beauty, Justice, Freedom, Value of life, Dignity.

Universal human values: Human, Life, Family, Homeland, World, Earth, Knowledge, Culture, Work.

Civic values: human rights, freedom, equality, justice, public goods for the entire people, patriotism etc.

Civic culture is subdivided into the political, legal, economic, labor, peace-making and environmental protection culture.

From the pedagogical viewpoint, civic spirit is considered as one's mastering and fulfilling one's rights and liabilities toward oneself as an individual, one's family, other people, the public, Homeland and the planet Earth. Civic spirit is an integral human quality, an essential stage in the human establishment and development. It is knowledge, abilities and their fulfillment in performing a person's civic rights in all spheres of the person's life activity that serve as the criteria of civic culture being formed with the person.

The conceptual ideas on shaping a citizen's personality from the school times outlined above will help bring up in citizens the true patriots loving their Motherland, their people and country dearly, teach them not only rights of the country's citizen but also their liabilities to both Motherland and the state, and shape in them the skills of fulfilling the above not only during learning and upbringing but also in extramural work and in the family, assisted by parents.

It is pointed out in the RF Law on education (2012) that in learning and upbringing of schoolchildren, particularities of culture and national traditions of peoples populating the country should be taken into account, and the national component of upbringing and educational programs has to occupy its due place. So, it is necessary to develop individuals without ripping them away from their roots - individuals possessing the feeling of national self-awareness, the feeling of Motherland, the feeling of patriotism; to improve the learners' level of knowledge about their Motherland, history, culture, traditions and customs of their people, to help them creatively use the latter in their daily life; and to set up the efficient dialogue of national cultures via creating extensive public, economic, political, and cultural relationships between peoples of individual regions and of the entire Russia.

The folk word of wisdom says, "seek the head if the river goes low". The contemporary conditions have it that the entire system of upbringing created in the past was destroyed, and nothing new has been created so far. So what is essential for the Russians today is to find the sources nourishing their morals, their self-awareness, their historical memory, their culture - ones to help spiritually revitalize the younger generations of citizens of the entire Russia, to help oppose the negative processes observed on the TV and in the mass media currently. This is why Russia has to use traditions of its ancestors in upbringing of the youth, ones that have proven their efficiency in forming the rising generations throughout millennia. It is quite easy to remember that a high level of spiritual and moral, esthetic culture, patriotic, labor, physical upbringing, family culture has been deteriorated in the recent 25 years. It is no mere chance that the great Russian pedagogue K. D. Ushinsky (1988) said "upbringing created by the people itself and based on the folk principles has that upbringing force which is not to be found in the best systems relying on 
abstract ideas" (p. 78).

Folk pedagogy clearly determines the basis which has to be put into the content of upbringing and education of children. It encompasses natural ideals, traditions, daily life, arts, lore, work, game, communication with the nature. Folk pedagogy brings one back to the roots as the foundation of the content, objective, and principles of bringing up a personality was laid, as well as the pedagogical technologies with which the formation process was quite efficient.

At present, pedagogical science pays special attention to forming such personal qualities that are directly associated with bringing up patriotism and civic spirit: truthfulness, clarity, modesty, faithfulness in friendship and love, laboriousness, the collective spirit feeling, love for Motherland and devotion to the interests of the people, high morals, spirituality, mercy, the feeling of duty, serving Motherland and the people, tolerance, etc. One's ancestors teach one to orient to the high culture, to such natural ideals as reality, truth, the good, beauty, justice, love for freedom, and in the process of one's self-fulfillment and self-identification to be guided by the wish to do good, to keep the cult of ancestors, the cult of traditional family, to manifest conscientious attitude to working for the benefit of the public and one's Motherland. As it can be seen these values are in demand in the today's upbringing, too, which has to be built relying on the traditions of the ancestors both at school, in the family and in the community.

Both in Dagestan and other republics, regional and national components of the curriculum of the secondary comprehensive school involve studying the culture and traditions of their peoples. The program provides for introducing the schoolchildren to the national sources of spiritual upbringing which form the best qualities of their people having become traditional ones and bring up new generations of mountaineers with them.

In the educational and upbringing process, the ancestors' best traditions are used, which is the practice not only for extramural work but also in studying such subjects as the history of the native land, native language, literature, music, arts, physical training. The curricula in these subjects also provides for studying the best traditions of peoples of the North Caucasus. At such classes, the students show their love for Motherland, its history, culture and art of the peoples, show their pride in the heroic history, courage, bravery and selflessness of characters of the epic literature; at PT classes, they are fond of various games and kinds of sports practiced by the old mountaineers.

In the present-day conditions, as the young generations rarely read books, spend more time watching television or with their telephones via which they broadcast more and more often films and programs that can teach children and youth robbing, killing, stealing, betraying their Motherland and fleeing abroad, violating elementary behavior standards, behaving in the public in an immoral way, it is the adults that have to come and help them, frequently explain the consequences of manifesting negative behavior norms, and teach them use the messages of ancestors.

Children have to be taken care of starting with the very small age, so that they could be proud of their parents as they grow up. Love for Homeland is known to begin with love for one's smaller Motherland, one's aul, area, republic. Almost up to their coming of age, children and adolescents know not only their smaller Motherland, and the love for greater Motherland, for the Russian Federation as their state, comes later; it is at the same time that they also feel the establishment of their civic spirit, and after serving in the army they turn into patriots with whom love for their great Motherland becomes conscious and conclusive. Writer V. V. Lichutin (2018) in his book "Soul inexplicable" says: "In the swift-flowing, ever changing world, in the times of looking for the truth and gaining the genuine truth, recognizing spiritual losses, the human soul needs something to lean on, something everlasting and balanced. People remember about their roots, origins, time-honored feelings of love and respect for one's native home as something that can connect and unite in the difficult time of change" (p. 122). This is why one has to remember the beauty of one's native region, city, village, one's history and the outstanding people who used to live in one's native land, their customs and traditions with the help of which small people become big. All this enables people to learn themselves, their ancestors, their particularities, moral standards, ideals and values. People start to become aware why they are exactly like that. Hence it is essential to introduce the young generation to the sources of self-understanding, without which the complete spiritual and creative development of personality is inconceivable, and so it is for one to realize one's belonging to one's people. 
In the school curriculum works of verbal folklore of each ethnos, the images of folk heroes are studied who served their Homeland faithfully and loyally, with courage and bravery, high morals, their beauty and physical perfection and have repeatedly saved their Motherland from foreign invaders. References to such heroes that allow learning about feats of the worthy sons and daughters and realizing them both in school education and in family upbringing will help form the ideal of a citizen of one's Homeland, a worthy person capable of not only loving but also protecting one's Motherland whenever it is necessary.

B. T. Likhachev (1997) said each people should be judged according to the moral heights and the ideals the people live by. The Russians are proud of their ancestors and they have something to learn from them. This is quite realistic in the contemporary education, if students are given the opportunity to gradually learn the entire depth of their national culture since the first form, if it is to be recognized that each of more than 150 peoples living in Russia has a special national culture of its own, if the Russian culture is understood as consisting of all these cultures, both big and small and the great Russian national culture with its national traditions as if cementing within it the cultures of all peoples making it up together.

By studying the culture and traditions of its peoples at schools, one goes on to the general Russian, and then on to general human culture while bearing in mind Russia's own originality. At the same time, the educational and upbringing process brings up such personal qualities as peoples' friendship, civic spirit (respect for the country's laws, adherence to them, knowing and fulfilling human rights and liberties, love for not only smaller Motherland, but for the greater one the Russian state, the great Motherland), working for the benefit of Motherland, tolerance, love and respect for all peoples populating the country, modesty and decency, national pride, respect for one's history, culture and art, native language, literature, traditions and customs.

Professor R. M. Rogova (2003) points out that "learning history at the secondary school covers the main spheres of public life in an organic unity: the economy, politics, ideology, culture. And it will be most efficient if integrative links are fulfilled with the economic geography, social studies, and literature, which will enable students to see the history of the society, the driving forces of its development, successes and defeats, the system of social relations as a whole and in its more important features reflected in science and arts. Forming the historical cognition, comprehension of the experience of history, perception of the ideas of humanism, respect for human rights, and patriotism in students is the paramount phenomenon of the civic spirit of an individual who accepts genuine, and not false, moral, national, and social values of the peoples of Russia and who is trying to enrich the spiritual legacy" (p. 203).

\section{Conclusion}

The research conducted has confirmed the initial hypothesis in general and has allowed making the following conclusions:

- in the legacy of ancestors, it is the knowledge of one's mother tongue, history, literature, arts, national traditions in one's family, a friendly attitude to people of various nationalities, preservation of customs, reverence for the older ones, careful attitude to the holy places and monuments of the ancient culture that has always been pushed to the foreground. This refers to all peoples living in Russia, both the supporters of Islam, Orthodox Christianity, Judaism, and representatives of other religious denominations;

- with regard to this, both the elements of national egoism, superiority, contrasting one nation to another one, and the elements of national nihilism and disdain toward the original, national culture of one's people which is fraught with negative consequences arising between citizens of one country are unacceptable, particularly among the young students;

- hence the main task of school and higher education institution teachers is to help the youth critically analyze extremism, terrorism, and chauvinism, to make a stand for the moral, esthetic, social values and to promote establishment of the civic spirit and patriotism with all peoples of Russia. 


\section{References}

Akhayan, T.K. (2016). Shaping the intellectual and moral convictions of public labor activity in schoolchildren. Sel. works of T.K. Akhayan. SPb: A.I. Herzen Russian State Pedagogical University.

Bazilevich, N.L. (1982). Problems of patriotic upbringing of primary school students in the pedagogical legacy of V.A. Sukhomlinsky: PhD thesis. Moscow.

Belyaev, N.I. (1997). Shaping ideas about phenomena of public life in children. Using the materials of familiarization with the modern army: PhD thesis abstract. Moscow.

Berdyaev, N.A. (1920). On patriotism, Russian national will, serving. Sel. works on philosophy. Moscow.

Boldyrev, N.I. (1949). Upbringing of Soviet patriotism in schoolchildren: lectures on pedagogy for teachers. Main lecture center of the All-Union society for propagation of political and scientific knowledge. Moscow: I.V. Stalin typography.

Dragomirov, M.I. (1956). Questions of upbringing and training of troops. Sel. works. Moscow: Voenizdat.

Filonov, G.N. (2003). Social and pedagogical activity within the context of establishment of the civic society. Materials of the $2^{\text {nd }}$ All-Russian scientific and practical conference "Upbringing of patriotism, friendship of peoples, and religious tolerance", 2001 (p. 30). Moscow.

Gamzatov, R.G. (1972). My Dagestan. Makhachkala.

Ganelin, Sh.I. (2001). The system of military and patriotic upbringing as a condition for the formation of personality of a cadet of military educational institutions of higher professional education: PhD thesis. Saratov.

Gasanov, Z.T. (1999). Pedagogy of international communication. Moscow.

Gasanov, Z.T. (1998). Upbringing of the culture of international communication: Methodology, theory, practice. Makhachkala: Publishing house of DSPU.

Goncharov, M.A. (2003). Patriotic upbringing: yesterday, today, tomorrow. Materials of the $2^{\text {nd }}$ All-Russian scientific and practical conference "Upbringing of patriotism, friendship of peoples, and religious tolerance", 2001 (p. 145). Moscow.

Ighenberdieva, L.Sh. (2006). Pedagogical system of heroic and patriotic upbringing of an individual in conditions of establishment of the civic society: PhD thesis. Magnitogorsk.

llyin on Russia (1995). Moscow: Russian archive.

Khairullin, R.Z. (2003). Literature as an important means for upbringing of students in the spirit of peace, patriotism, and friendship of peoples. Materials of the $2^{\text {nd }}$ All-Russian scientific and practical conference "Upbringing of patriotism, friendship of peoples, and religious tolerance", 2001 (p. 297). Moscow.

Kornilov, V.A. (2010). Section "Art of war" in 15 vol. Vol. 3. Moscow.

Law "On education in the Russian Federation" No. 273-FZ dated December 29, 2012 (2012). Retrieved from http://www.consultant.ru/document/cons doc LAW 140174/ on August 7, 2019.

Leontiev, A.I. (1975). Activity, consciousness, personality. Moscow: Politizdat.

Lichutin, V.V. (2018). Coll. works in 2 vol. Vol. 1. Soul inexplicable. Moscow: Veche publishers.

Likhachev, B.T. (1997). Introduction to the theory and history of upbringing values. Historical analysis of upbringing values in Russia of the $19^{\text {th }}$ and $20^{\text {th }}$ centuries. Samara: Publishing house of SIM.

Mishchenko, L.I. (1982). Patriotic upbringing of primary school students: PhD thesis. Moscow.

Nikandrov, N.D. (2003). Russian national idea - the basis for upbringing. Materials of the $2^{\text {nd }}$ All-Russian scientific and practical conference "Upbringing of patriotism, friendship of peoples, and religious tolerance", 2001 (pp. 13-22). Moscow.

Plakhova, T.V. (2003). From a citizen of a country to a citizen of the world. Materials of the $2^{\text {nd }}$ All-Russian scientific and practical conference "Upbringing of the Russian patriotism, friendship of peoples, and the civic spirit", November 14-15, 2003 (p. 193). Moscow.

Pushkin, A.S. (2005). Two feelings are wondrously close to us. Poetry (civic poems). Coll. works in 10 vol. Moscow.

Radishchev, A.N. (2000). Development of humanistic view of the world and value references of people. Moscow: Politika.

Rogova, R.M. (2003). Formation of historic consciousness as a phenomenon of civic spirit of an individual. Materials of the $2^{\text {nd }}$ All-Russian scientific and practical conference "Upbringing of patriotism, friendship of peoples, and religious tolerance", 2001 (p. 207). Moscow.

Rozanov, V.V. (1980). The Twilight of Enlightenment. SPb.

Rubinshtein, S.L. (1997). Fundamentals of ontology, logic, and psychology. Sel. works on philosophy and psychology, RAS Institute of psychology. Moscow: Nauka.

Shakhnenko, V.I. (1984). Patriotic upbringing of adolescent offenders in conditions of special school: PhD thesis. Moscow.

Soldatenko, A.D. (1994). Orienting schoolchildren to spiritually important values. Moscow.

Soloviev, V.S. (2019). National problem in Russia. Moscow: Publishing house of AO RAIT. 
Stroev, E.S. (2001). On patriotism. Moscow.

Suvorov, A.V. (1942). Science of victory. Sverdlovsk: OGIZ.

Tarman, B., Chigisheva, O. (2017). Transformation of educational policy, theory and practice in post-soviet social studies education. Journal of Social Studies Education Research, 8(2), pp. I-IV

Terentiy, M.A. (1978). Theory and practice of patriotic and international upbringing of the rising generation. Chisinau.

The UN Convention on the Rights of the Child (1987). Moscow. Retrieved from http://www.consultant.ru on August 7, 2019.

Ushinsky, K.D. (1988). On the national spirit in public upbringing. Ped. works in 6 vol. Vol. 1. Moscow.

Ushinsky, K.D. (1968). Selected ped. works. Moscow: Prosveshchenie.

Vanshtein, A.D. (2011). Specific features of patriotism in conditions of cultural globalization: PhD thesis. Rostovon-Don.

Vygotsky, L.S. (1991). Educational psychology. Moscow: Pedagoghika. 